\title{
Factors affecting entrepreneurial intention: evidence from Khulna University, Bangladesh
}

\author{
Sraboni Akter ${ }^{1 *}$ Saimur Rahman ${ }^{2}$
}

Human Resource Management Discipline, Khulna University, Khulna, Bangladesh 1,2 sraboniakterhrm@gmail.com ${ }^{1}$, saimku77@ gmail.com ${ }^{2}$

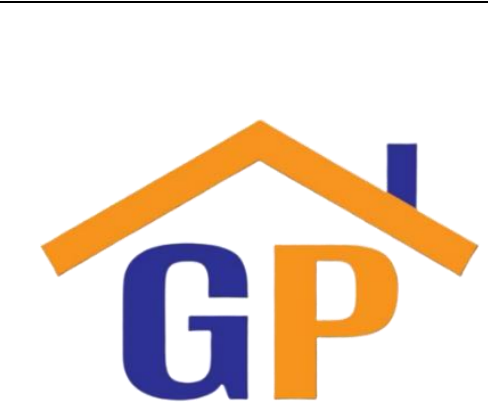

Article History

Received on 16 January 2021

$1^{\text {st }}$ Revision on 19 January 2021

$2^{\text {nd }}$ Revision on 25 January 2021

Accepted on 26 January 2021

\begin{abstract}
Purpose: This study aimed to investigate the influence of factors affecting entrepreneurial intention and finally show the relationship between those factors on entrepreneurial intention.
\end{abstract}

Research methodology: This study used explanatory and inferential methods. Data was collected using a closed-ended questionnaire. The program used was SPSS Version 16.00.

Results: We found a positive and significant relationship with all the factors besides entrepreneurial education and gender differences.

Limitation: The study is limited to the respondents' bias and restriction to only one particular university.

Contribution: This study's results contribute to understanding the importance of entrepreneurial education to the university and arranging more seminars and case study and introducing some inspired entrepreneurs for the student's betterment.

Keywords: Autonomy, Entrepreneurial education, Entrepreneurial intention, Need for achievement, Locus of control

How to cite: Akter, S., \& Rahman, S. (2020). Factors affecting entrepreneurial intention: evidence from Khulna University, Bangladesh. Journal of Sustainable Tourism and Entrepreneurship, $1(3), 255-267$.

\section{Introduction}

There has been worldwide attention on private enterprise as a cure for sustainable regaining from the economic breakdown and entrepreneurial intention dramatically affects it. Many scholars believe that entrepreneurial goal is alike to further personality qualities such as locus of control, despite some differences (Boyd \& Vozikis, 1994). Self-efficacy is one of the central mechanisms of risk-taking intention models (Ajzen, 2002). The past era has seen the speedy expansion of intention in entrepreneurship debates, especially traits of personal competence and control (Krueger \& Brazeal 1994). Self-efficacy has been theoretically and analytically interrelated to both entrepreneurial intentions and occupation advancement. Pihie \& Bagheri (2011) inspected teachers' and students' entrepreneurial intention and found out that students apparent their capabilities to do well as simply modest. Fiet (2000) stated that Purposeful education increases students' entrepreneurial intention by providing the understanding of the command, role models, and social encouragement. Bandura (1999) stated that intention is fundamental in the entrepreneur's task. Additionally, to triumph stockholders' assurance, an ambitious entrepreneur needs to demonstrate the skills and proficiencies that are desirable to succeed which completed entrepreneurial intention (Kasouf et al., 2013).

Over the earlier years, choosing to start a novel business or convert to an entrepreneur had been scrutinized using innumerable facets. The up-to-date tactics focused on the presence of firm entrepreneurial intention characters that could be escorted by an entrepreneurial intention. It pointed quite a few aspects such as a high need for achievement (Matlay et al., 2013) a desire for autonomy (Davidsson, 1995) need for power (McClelland, 1961) propensity to take the risk (Brice, 2007) need for affiliation (McClelland, 1961) internal locus of control (Begley and Boyd, 1987) and tolerance of 
ambiguity (Smilor, 1997). It also acquaintances with several demographic variables such as age, gender, family background, religion, education, experience (Reynolds et al, 1994).

In a developing country like ours, entrepreneurship plays a vibrant role and the undergraduates mainly take a step forwards to their entrepreneurial career. There have some disputes over entrepreneurial intention which designates that there has a noteworthy research gap. Besides that, there has been no significant research on this aspect, especially among Khulna University students. So, this research's main plan is to find out the key factors that affect entrepreneurial intention as well as to show the relationship between factors and entrepreneurial intention.

\section{Literature review and hypothesis development}

\subsection{Entrepreneurial intentions}

Katz (1992) described that employment position choice intentions as the occupational verdict process whether he desires to engage in a remunerated job or self-starting business. Kolvereid (1996) argued that a person's perceived interactive control has a robust intention to become an entrepreneur. The apparent behavioral regulator is one of the crucial influencers of a person's belief which has been found to the critical stimulus to boost entrepreneurial actions and intentions (Krueger et al., 2000). Entrepreneurial intentions are unsurprisingly considered to be molded by an individual's insolence toward entrepreneurship (Krueger et al., 2000). Thus, the entrepreneurial intention is a cognizant state of awareness that leads to consideration and deed toward entrepreneurial actions (Bird, 1998). The entrepreneurial intention has confidence in that new occupational formation is a purposely strategic behavior (Krueger and Carsrud, 1993). According to Dixon et al., (2005), entrepreneurship programmed proposed to the students to enhance entrepreneurial vital aids and intention for an innovative venture.

Three factors influence entrepreneurial intentions: first, a person's attitude towards entrepreneurship, the second factor is perceived social norms, such as family, friends, colleagues, and customers and the third factor is self-efficacy (Krueger et al., 2000). Peripheral stimuli like demographics, skills and society, traits, financial support, and culture also indirectly help entrepreneurs become entrepreneurs (Shapero and Sokol, 1982). Numerous studies have revealed that family business contact inspires people's entrepreneurial intentions hence, the business family has been called the social standing ground of imminent entrepreneurs (Carr and Sequeira, 2007). Nonetheless, Brenner et al., (1991) and Gird and Bagraim, (2008) found no vital relationship between parental entrepreneurs and youngsters' entrepreneurial intentions. In some research studies, efforts have been made to abundant entrepreneurial explanations as perceived by the businesspersons themselves. Mcclelland, (1961) acknowledged the 'need for achievement' as the only most imperative factor of entrepreneurial drive. Hornaday and bunker, (1970) correspondingly reinforced McClelland's interpretation because of achievement cause as an explanatory variable for entrepreneurial actions. Collins and Moore, (1970) documented independence as a chief source of entrepreneurial motive. Supplementary, Hornaday, and aboud, (1970) conveyed that the need for achievement, support, independence, and leadership are the most significant tactical features of an entrepreneur.

\subsection{Factors affecting entrepreneurial intention and their relationship}

Over the ages, the possibility to set up a new profession or become an entrepreneur has been scrutinized through countless aspects. An entrepreneurial goal could escort the latest styles engrossed with convinced commercial self-efficacy traits. It pointed several factors such as a high need for achievement (Matlay et al., 2013) a desire for autonomy (Davidsson, 1995), need for power (McClelland, 1961), propensity to take risk (Brice, 2002), need for affiliation (McClelland, 1961), internal locus of control (Begley and Boyd, 1987) and tolerance of ambiguity (Smilor ,1997) Demographic factors such as age, sex, education, work experience (Ismail et al.,2009). Mazzarol et al., (1999) found that females are not as much of an entrepreneurial soul when equated to males. Brush (1992) initiated that menfolks are more motivated in the entrepreneurial profession's direction than womenfolk. Predominantly, women businesspersons confronted additional trouble in arranging money to begin a business as well as an inferior grade of social capital like schooling and labor involvement (Boden \& Nucci, 2000). Rerup $\underline{(2005)}$ specified that with former experience are more probable gradient on the way to private enterprise. So, the aspects which are interrelated with entrepreneurial intention are given below: 


\section{Risk-taking propensity}

Risk-taking tendency encompasses a wide-ranging inclination or desire, to follow or dodge risks in a precise kind of choice background (Sitkin \& Pablo, 1992). This means that when a distinct person is confronted with unlike surroundings, will likely reveal dissimilar risk tendencies. In Sitkin and Pablo's (1992) theoretical model, risk propensity has a distinguished role in operating risk perception and risk behavior and recommended that risk-averse decision-makers are more likely to join undesirable consequences, miscalculating threats, and undervaluing chances, and risk-seeking decision-makers tend to attend constructive consequences.

Zhao et al (2005) surveyed the rapport of risk propensity to entrepreneurial intention, which appears to have a positive connection. The variance between the two kinds of risk is the amount to which the decision-maker has regulation over the result (Weinstein, 1984). Persons are considerably more likely to take the risk when the outcome of the act hinges on their skills rather than on coincidence. Krueger and Brazeal (1994) showed a path analysis and exhibited that self-assurance inclined the awareness of chances of achievement and disappointment which in turn influenced the tendency to take the risk and therefore, there is a positive relationship between self-assurance and risk-taking in skill-related situations. Thus, we assume the subsequent relationship:

Hypothesis 1: Risk-Taking Propensity has a positive relationship with Entrepreneurial Intention.

\section{Autonomy}

Autonomy denotes to go-getting approach towards the progression of individual goals, morals, and benefits (Assor et al.,2002). Many research exposed that entrepreneurial inspiration does not rest on economic advantage, nonetheless on autonomy (Van Gelderen and Jansen, 2006). Prottas (2008) offered that autonomy is a foremost for entrepreneurial motivation and the main foundation of entrepreneurial gratification and Autonomy is strongly connected with entrepreneurship because of the decisional liberties.

According to Gibb (2002), means of a lifetime are characterized by ambiguity, transformation, and complication. On the other hand, independence, individual obligation, and autonomy are critical for an individual. Van Gelderen and Jansen (2006) labeled that ample desired self-government to have the freedom to make their particular choices and the requirement for autonomy can also be a prerequisite for the contentment of other causes. The self-determination theory found an active assignation in entrepreneurial responsibilities to be strongly linked with autonomy Dada, \& Watson, (2013). Therefore, we expect the following relationship:

Hypothesis 2: Autonomy has a positive relationship with Entrepreneurial Intention.

\section{Need for achievement}

Mcclelland (1961) defined that favorites for a challenge, taking of own accountability for outcomes, and innovativeness are recognized abilities linked with a high need for achievement and those features are stirring individuals to initiate innovative ventures as well as contributing to project success (Hornaday and Aboud, 1971). Hisrich (1990) distinguished that entrepreneurial actions require ingenuity and inventive intelligence, which able to establish social and economic instruments to turn capitals and circumstances into accomplishment. Mcclelland (1961) proposed alike traits to clarify entrepreneurial behavior such as a high need for achievement, risk-taking propensity, a penchant for spirited activity, and personal responsibility for victory and distress. Therefore, we expect the following relationship:

Hypothesis 3: Need for achievement has a positive relationship with Entrepreneurial Intention.

\section{Locus of control}

Rotter (1990) contributed to the development of locus of control research, which quantified a separate result of an incident beneath his resistor. An individual with an inner locus of control effects results in aptitude, determination, or skills. An individual with an exterior locus of control has faith that his behaviors are under the impact of outside forces. The relationship between entrepreneurial behavior and 
internal locus of control has a positive connection (Perry 1990; McClelland 1961). Shapero (1975) introduced a high score between entrepreneurs and internal locus of control alignment.

Individuals with an internal locus of control have stable confidence that they control the whole thing happenings in their own life, whereas people with an external locus of control state events to external factors, such as destiny, chance, or fluke. Empirically it is verified that internal locus of control is one of the foremost traits of entrepreneurs, and can be a great factor in the triumph of an initiative (Robinson et al.,1991). Therefore, we expect the following relationship:

Hypothesis 4: Locus of control has a positive relationship with Entrepreneurial Intention.

\section{Entrepreneurship education}

Dyer (1994) recommended that entrepreneurship courses or training contribute to starting a new business and self-confidence and inspiration. Engrossed schooling lifts pupils' entrepreneurial value through attitudes, familiarity, and skills to handle the difficulties and opportunity-seeking (Wilson, et al., 2007). In actual fact, education augments students' entrepreneurial effectiveness by providing an understanding of mastery, role models, social persuading and business plan development, and running an imitation of actual small business (Fiet, 2000). Jo \& Lee, (1996) whispered that entrepreneurs with entrepreneurial teaching and experience can generate higher returns than those who have no schooling. Entrepreneurial education agendas are a basis of entrepreneurial attitude and general goals (Souitaris et al.,2007). Entrepreneurship education has been allied to an upsurge in the entrepreneurial intention of latent entrepreneurs (Chell, 2000). Yet, entrepreneurial intentions among engineering and science students are near to the ground compared with those of commerce students and this may be because of entrepreneurship education. A substantial number of works have been issued on entrepreneurial intention and found a positive relationship between entrepreneurship education and entrepreneurial intention (Westhead \& Solesvik (2016).Bernstein \& Carayannis, (2012) also found that entrepreneurial intention among non-business students occurs because of entrepreneurship courses. Therefore, we expect the following relationship:

Hypothesis 5: Entrepreneurship education has a positive relationship with Entrepreneurial Intention.

\section{Family background}

Carr and Siqueira (2007) first verified that domestic business experience influences entrepreneurial intentions in the viewpoint toward business start-ups, family backup, and entrepreneurial self-efficacy and detected that parental business involvement aids on intentions to turn out to be an entrepreneur. Current studies specified that a family with a business upbringing inspires and persuades to encompass in the entrepreneurial venture in the forthcoming period (Sata, 2013). Drennan et al., (2005) found that students with family business experiences seeming to start a business as both desirable and achievable. According to Zellweger et al., (2011), business family descendants are expectant about their facilities to chase a business career but are doubtful about monitoring that entrepreneurial profession.

Scherer et al., (1989) claimed that paternities show a decisive role in promoting their offspring's education progression. The upshot of the family socialization atmosphere, opinions, and observations on how broods pick up new perceptions are significant and children whose paternities are self-employed are found to either start original ventures or endure the family business's running as a career. Carr and Siqueira, (2007) former contribution in family-possessed business has a constructive influence on entrepreneurial intention. Scherer et al., (1989) highlighted the protagonist of family circumstances, beliefs, and duties in children's culture and sustained that the communal atmosphere of young ones has a significant influence on their entrepreneurial attitudes. Youngsters' vocations are also affected by their outlook throughout the family business engrossment (Murphy and Lambrechts, 2015). Therefore, we expect the following relationship:

Hypothesis 6: The family background has a positive relationship with Entrepreneurial Intention.

\section{Gender}

It is thought that extended tenure explanations to lessen gender discrepancy in entrepreneurship have to commence in the educational structure (Díaz-García \& Jiménez-Moreno, 2010). From a demographic standpoint, it is well acknowledged that there exist variances and studies across gender and entrepreneurial behavior as well as attitudes towards novel venture formation_(Delmar \& Davidsson, 
2000). Some studies that have by now evaluated this influence presented that men have a greater fondness for entrepreneurship behavior than women (Delmar \& Davidsson, 2000).

Maes et al., (2014) designated miscellaneous aspects that forecast gender alterations in entrepreneurial determined by using the Theory of Planned Behavior (TPB). The fallouts of an investigation with business students point to that the conclusion of gender on entrepreneurial intentions is arbitrated via personal attitudes and perceived behavioral control but not social rules. More exactly, women are further ambitious on the way to entrepreneurship by purposes to a sense of balance that is fewer, leading to a particular attitude. Likewise, female undergraduates are slightly less motivated toward entrepreneurship by theories of inner control that are more overriding in predicting apparent control. Therefore, we expect the following relationship:

Hypothesis 7: Gender has a positive relationship with Entrepreneurial Intention.

\section{Previous business experience}

Shane (2003) was renowned for the effect of earlier skills on the businessperson. Unambiguously, he found that wide-ranging business, efficient, industry, and start-up experiences all separately projected self-service. Shane (2000) also pointed out that former facts about marketplaces, client complications, and knowledge about how to attend marketplaces will affect persons' detection of openings, therefore inducing risk-taking behaviors. These types of knowledge naturally can be rooted in a person's occupation experience. Bandura (1986) documented that through experience, what he called mastery experience, was a commanding education method. This advocates that students holding any experience in establishments are more expected than those without such experiences to pursue self-employment opportunities. Placements in entrepreneurial corporations and heartening participation in student-run trades would be significant in this respect. Also, Kuehn (2008) proposed that students should be encouraged to engross in student-squad consulting plans to trivial businesses as a portion of their knowledge experience. All these activities replicate the learning experiences that are so powerful in edifice our forthcoming views. Correspondingly, erstwhile exposure to entrepreneurship impacts entrepreneurial intentions (Basu \& Virick, 2010).

Mair and Noboa (2006) completed a model by accumulating prior involvement with community establishments as a new precursor of social entrepreneurial intentions. Familiarity with the kind of problems social enterprises purpose to solve is presumed to be an initiation for intention development. Besides, it will be claimed that the backgrounds recommended by Mair and Noboa intercede the effect between experience and intentions. Carr \& Sequeira, (2007) acknowledged prior household experience as well as prior work experience to be forecasters of business intent. Therefore, we expect the following relationship:

Hypothesis 8: Previous business experience has a positive relationship with Entrepreneurial Intention.

\section{Research Methodology}

\subsection{Sample}

The study sample comprised of 100 for a precision of $10 \%$ (Singh, and, Masuku, 2014) university students selected from Khulna University Bangladesh from the various department from $1^{\text {st }}$ year to MBA. It was found that $17 \%$ of the respondents between 15-20 and 83\% were between 21 and 25. Data also represented that $60 \%$ of the respondents were male and $40 \%$ of the respondent were female. Among the respondents, $34 \%$ had previous business experience and $66 \%$ had no previous business experience. For the respondents' education level, $12 \%$ were 1st year, $17 \%$ were 2nd year, $20 \%$ were 3rd year, 36\% were 4th year and rest were postgraduate students.

\subsection{Research instrument}

Data used in this study was collected through online or offline a self-administered questionnaire. But few of the respondents were able to provide information through the self-administered questionnaire as many of the sample students were quite unaccustomed to the survey questionnaire. A close-ended questionnaire with 35 statements was used for this survey. The questionnaire had three sections. In section, A the demographic profile of the respondents was mentioned and section B contained factors 
such as family support, risk-taking propensity, autonomy, entrepreneurial education, and locals of control. Finally, in the third part, entrepreneurial intention criteria were mentioned. For this questionnaire 5-point, Likert scale was used. Here $\mathrm{SD}=$ Strongly Disagree, $\mathrm{MD}=$ Moderately Disagree, $\mathrm{N}=$ Neutral, MA= Moderately Agree, $\mathrm{SA}=$ Strongly Agree.

In this study, the research instruments were taken from Family support (Basu \& Virick, n.d., 1993), Entrepreneurial Education_(Dyer ,1994), Locus of Control_(McClelland ,1961), Autonomy (Uddin \& Bose ,2012) Need for Achievement_(McClelland ,1961) Risk Taking Propensity (Boyd and Vozikis, 1994) and Entrepreneurial Intention_(Krueger and Carsrud, 1993). research as information that could be obtained and studied in order to draw conclusions.

\section{Results and discussions}

\subsection{Reliability of measure}

Reliability analysis refers to the test of the consistency of respondents' responses to all the things in a measure or the extent to which an instrument measures the same way every time it is utilized under the same condition with the same subjects. The higher the coefficient, the better is the reliability of what the instrument intends to measure.

Table:1 Data Reliability

\begin{tabular}{cc}
\hline Cronbach's Alpha & N of Items \\
\hline .909 & 35 \\
\hline
\end{tabular}

Source: Field Survey

From the table, we can see that the data set's reliability value is .909 which is above the suggested value of .70 and is marked as good (Tavakol \& Dennick, 2011). So, it is cleared by the value shown by Cronbach's Alpha is the data used for this research is reliable.

\subsection{Correlation analysis}

Table 2. Pearson Product-Moment Correlations between Study Variables

\begin{tabular}{|c|c|c|c|c|c|c|c|}
\hline Variables & 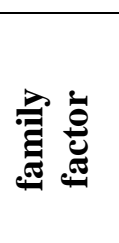 & لِّ & 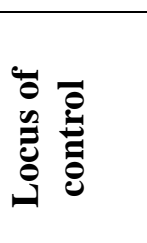 & 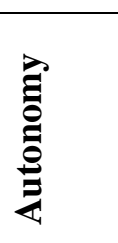 & 咅 & 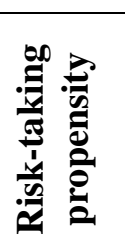 & 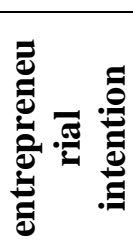 \\
\hline family factor & 1 & & & & & & \\
\hline $\begin{array}{l}\text { entrepreneurial } \\
\text { education }\end{array}$ & .097 & 1 & & & & & \\
\hline Locus of control & .143 & $.609 * *$ & 1 & & & & \\
\hline Autonomy & -.041 & $.582 * *$ & $.599 * *$ & 1 & & & \\
\hline $\begin{array}{c}\text { Need for } \\
\text { achievement }\end{array}$ & .081 & $.447 * *$ & $.506 * *$ & $.715^{* *}$ & 1 & & \\
\hline $\begin{array}{l}\text { Risk-taking } \\
\text { propensity }\end{array}$ & $.227^{*}$ & $.613 * *$ & $.585^{* *}$ & $.674 * *$ & $.584 * *$ & 1 & \\
\hline $\begin{array}{l}\text { entrepreneurial } \\
\text { intention }\end{array}$ & $.259 * *$ & $.459 * *$ & $.480 * *$ & $.589 * *$ & $.560 * *$ & $.703 * *$ & 1 \\
\hline
\end{tabular}

**. Correlation is significant at the 0.01 level (2-tailed).

*. Correlation is significant at the 0.05 level (2-tailed). 
In these results, the correlation between risk-taking propensity and entrepreneurial intention is .703, indicating a moderate positive relationship between the variables. The p-value of the correlation between risk-taking propensity and entrepreneurial intention is significant at 0.000 . This indicates that it is less than .001, which suggests that the correlation coefficient is statistically significant.

In these results, the correlation between autonomy and entrepreneurial intention is .589, indicating a moderate positive relationship between the variables. The p-value of the correlation between autonomy and authority \& entrepreneurial intention is significant at 0.000 , this indicates that is less than .001 , which indicates that the correlation coefficient is statistically significant.

In these results, the correlation between the need for achievement and entrepreneurial intention is .560, indicating a moderate positive relationship between the variables. The p-value of the correlation between the need for achievement and entrepreneurial intention is significant at 0.000 , this indicates that is less than .001, which indicates that the correlation coefficient is statistically significant.

In these results, the correlation between locus of control and entrepreneurial intention is .480, indicating a weak positive relationship between the variables. The p-value of the correlation between Locus of control and entrepreneurial intention is significant at 0.000 , this indicates that is less than .001, which indicates that the correlation coefficient is statistically significant.

In these results, the correlation between entrepreneurial education and entrepreneurial intention is .459, indicating a weak positive relationship between the variables. The p-value of the correlation between entrepreneurial education and entrepreneurial intention is significant at 0.000 , this indicates that it is less than .001 , which suggests that the correlation coefficient is statistically significant. In these results, the correlation between the family factor and entrepreneurial intention is .259 , indicating a weak positive relationship between the variables. The $\mathrm{p}$ values of the correlation between the family factor and entrepreneurial intention are significant at 0.009 , this shows that it is not less than .001 , which indicates that the correlation coefficient is not statistically significant.

\section{3. regression analysis}

Table: 3 Model Summary

\begin{tabular}{ccccc}
\hline Model & R & R Square & Adjusted R Square & $\begin{array}{c}\text { Std. Error of the } \\
\text { Estimate }\end{array}$ \\
\hline $\mathbf{1}$ & .743 & .552 & .523 & .52696 \\
\hline
\end{tabular}

a. Predictors: (Constant), risk-taking propensity, family factor, locus of control, need for achievement, entrepreneurial education, autonomy.

This table shows that the adjusted R Square is .523, from these results $52.3 \%$ entrepreneurial intention is explained by the predicting variable (risk-taking propensity, family factor, locus of control, need for achievement, entrepreneurial education, autonomy).

Table: 4 ANOVA

\begin{tabular}{cccccc}
\hline & $\begin{array}{c}\text { Sum } \\
\text { Squares }\end{array}$ & df & $\begin{array}{c}\text { Mean } \\
\text { Square }\end{array}$ & F value & $\begin{array}{c}\text { Sig. } \\
\text { (p-value) }\end{array}$ \\
\hline Regression & 31.796 & 6 & 5.299 & 19.084 & .000 \\
\hline Residual & 25.825 & 93 & .278 & & \\
\hline Total & 57.620 & 99 & & & \\
\hline
\end{tabular}

\section{Source: Survey Data}


a. Dependent Variable: entrepreneurial intention.

b. Predictors: (Constant), risk-taking propensity, family factor, locus of control, need for achievement, entrepreneurial education, autonomy, and authority.

The significance value in the table shows the goodness of the model. The significance value is .000, indicating that the model used in this study fits with the data because the lower the significance value the better the model fits.

Table: 5 Linear Regression model-based estimated effects of selected covariates

\begin{tabular}{|c|c|c|c|c|c|}
\hline Model & $\begin{array}{c}\text { Unstandardized } \\
\text { Coefficients } \\
\text { (Estimated) }\end{array}$ & Std. Error & $\begin{array}{c}\text { Standardize } \\
\mathbf{d} \\
\text { Coefficients } \\
\text { (Estimated) }\end{array}$ & $\begin{array}{c}\mathbf{t} \\
\text { value }\end{array}$ & $\begin{array}{c}\mathbf{p} \\
\text { value }\end{array}$ \\
\hline (Constant) & .053 & .372 & .143 & .886 \\
\hline Family factor & .158 & .080 & .147 & 1.969 & .052 \\
\hline $\begin{array}{c}\text { Entrepreneurial } \\
\text { education }\end{array}$ & -.021 & .102 & -.020 & -.208 & .836 \\
\hline \begin{tabular}{c} 
Locus of control \\
\hline $\begin{array}{c}\text { Autonomy and } \\
\text { authority }\end{array}$
\end{tabular}$\quad .023$ & .121 & .018 & .187 & .852 \\
\hline $\begin{array}{c}\text { Need for } \\
\text { achievement }\end{array}$ & .137 & .096 & .174 & 1.422 & .158 \\
\hline $\begin{array}{c}\text { Risk-taking } \\
\text { propensity }\end{array}$ & .561 & .131 & .152 & 1.487 & .140 \\
\hline
\end{tabular}

\section{Source: Survey Data}

Dependent Variable: Entrepreneurial intention.

This study's regression results reveal a positive and significant relation between risk-taking propensity and entrepreneurial intention, with the estimated value of .465 and $(p<0.000)$. From these results, risktaking propensity contributes $46 \%$ to entrepreneurial intention. The risk-taking propensity to entrepreneurial intention is .000 denoting that a unit increase in risk-taking propensity would increase entrepreneurial intention by a factor of 4.279. The results explore that hypothesis is validated. The result was further evidenced in the study of (Boyd and Vozikis, 1994) disclosed that self-confidence predisposed the observation of probabilities of accomplishment and disappointment which in turn inclined the tendency to take the risk and thus, there is a positive relationship between entrepreneurial intention and risk-taking preparedness.

This study's regression results reveal a positive and significant relation between autonomy and entrepreneurial intention, with the estimated value of .174 and $(\mathrm{p}<0.000)$. From these results, autonomy and authority contribute $17.4 \%$ to entrepreneurial intention. Autonomy and authority to entrepreneurial intention are .158 denoting that a unit increase in autonomy and authority would increase entrepreneurial intention by a factor of 1.422 . The results explore that hypothesis is validated. The result was further demonstrated in the study of Prottas (2008), which existed that autonomy is a central point for entrepreneurial motivation and the main foundation of entrepreneurial satisfaction and Autonomy is strongly connected with entrepreneurship intention because of decisional independence.

This study's regression results reveal a positive and significant relation between the need for achievement and entrepreneurial intention, with the estimated value of .152 and $(p<0.000)$. From these results, the need for achievement contributes $15.2 \%$ to entrepreneurial intention. The need for achievement to entrepreneurial intention is .140 denoting that a unit increase in the need for 
achievement would increase entrepreneurial intention by a factor of 1.487. The results explore that hypothesis is validated. The result was further evidenced in the study of_McClelland,(1961) defined that penchants for a task, receiving of personal accountability for outcomes, and innovativeness are accepted potentials allied with a high need for achievement and those characteristics are motivating individuals to initiate entrepreneurship.

This study's regression results reveal a positive and significant relation between the locus of control and entrepreneurial intention, with the estimated value of .018 and $(\mathrm{p}<0.000)$. From these results, locus of control contributes $18 \%$ to entrepreneurial intention. Locus of control to entrepreneurial intention is .852 denoting that a unit increase in the locus of control would increase entrepreneurial intention by a factor of.187. The results explore that hypothesis is validated. The result was further shown in the study of (Robinson et al.,1991) in which they explicated that internal locus of control is one of the major qualities of entrepreneurs and a big basis of the victory of an initiative.

This study's regression results reveal negative and significant relation between entrepreneurial education and entrepreneurial intention, with the estimated value is -0.020 and $(\mathrm{p}<0.000)$. From these results, entrepreneurial education contributes $-2 \%$ to entrepreneurial intention. Entrepreneurial education with entrepreneurial intention is .836 denoting that a unit increase in entrepreneurial education would lead to a decrease in entrepreneurial intention by a factor of -.208 . The results explore that hypothesis is not validated. Although $($ Chell, 2008) evidenced that intensification has accompanied entrepreneurship education in latent entrepreneurs' entrepreneurial intention.

This study's regression results reveal a positive and significant relation between the family factor and entrepreneurial intention, with the estimated value being 0.147 and $(p<0.000)$. From these results, the family factor contributes $14.7 \%$ to entrepreneurial intention. The family factor with entrepreneurial intention is .052 denoting that a unit increase in the family factor would increase entrepreneurial intention by a factor of 1.969 . The results explore to validate the hypothesis. The result was additional evinced in the study of Zellweger et al., (2011), in which they enlightened that most business family descendants are positive about their capacity to follow an entrepreneurial job but are distrustful about directing that entrepreneurial profession.

\subsection{T-test}

Gender differences in entrepreneurial intention

Table: 6 Independent $t$-test analysis of gender differences based on entrepreneurial intention

\begin{tabular}{|l|l|l|c|c|c|c|}
\hline $\begin{array}{l}\text { Respondent } \\
\text { s' Gender }\end{array}$ & & $\begin{array}{l}\text { Frequenc } \\
\mathbf{y}\end{array}$ & Mean & $\begin{array}{c}\text { Std. } \\
\text { Deviation }\end{array}$ & $\begin{array}{c}\mathbf{t} \\
\text { value }\end{array}$ & $\begin{array}{c}\mathbf{p} \\
\text { Value }\end{array}$ \\
\hline & Male & 60 & 3.4733 & .85725 & \multirow{2}{*}{7.513} & .007 \\
\cline { 2 - 7 } & Female & 40 & 3.3250 & .59345 & & \\
\hline
\end{tabular}

Source: Field Survey

The results in the table showed that there have significant gender differences could be observed. As the $\mathrm{P}$-value of the outcome variables is less than 0.05 , there is no significant effect among the independent groups (male and female). 


\section{Prior business experience in entrepreneurial intention \\ Table: 7 Independent t-test analysis of prior business experience differences based on entrepreneurial intention}

\begin{tabular}{|l|l|c|c|c|c|c|}
\hline $\begin{array}{c}\text { Respondents' } \\
\text { Gender }\end{array}$ & Frequency & Mean & $\begin{array}{c}\text { Std. } \\
\text { Deviation }\end{array}$ & $\begin{array}{c}\text { t } \\
\text { value }\end{array}$ & $\begin{array}{c}\text { p } \\
\text { Value }\end{array}$ \\
\hline \multirow{2}{*}{} & Yes & 34 & 3.2539 & .70377 & \multirow{2}{*}{1.757} & .188 \\
\cline { 2 - 7 } & No & 66 & 3.4970 & .78387 & & \\
\hline
\end{tabular}

Source: Field Survey

The results in the table showed that there are no significant prior business experience differences could be observed. As the p-value of the outcome variables is more than 0.05 and then there is a significant effect among the independent groups (yes and no). The results explore to validate the hypothesis. The outcome was additionally demonstrated in the study of Shane (2003) noted the impact of previous involvement on the entrepreneur. Precisely, he found that general trades, manufacturing, and start-up experiences all individually foreseen as self-employment.

\section{Conclusion}

This study's general goal was to discover the significant aspects that affect entrepreneurial intention and display the relationship between factors and entrepreneurial intention. All the p-values for all the variables were found to be less than 0.05 , which indicates a statistically significant relationship for some variables. The study established that family factors, risk-taking propensity, need for achievement, locus of control, autonomy and authority have a positive relationship with entrepreneurial intention while entrepreneurial education and gender have negative relation although many empirical shards of evidence exhibited that it was one of the vital aspects. Among all the factors autonomy and authority have the most significance for entrepreneurial intention.

From the summary and conclusion, this study recommends that:

- The university should try to make entrepreneurial education compulsory for all disciplines to get the required knowledge.

- The university should try to do more seminars and case studies to get practical knowledge and introduce some inspired entrepreneurs to the students for their betterment.

From the general objective of the study and the research discoveries, additional studies should be done on a very similar matter and cover a broader scope such as the other university students and can differentiate based on academic background.

\section{Acknowledgment}

As the study is self-funded, the authors wish to thank Khulna University students who had voluntarily helped collect data used in the study.

\section{References}

Ajzen, I. (2002). Perceived behavioral control, self-efficacy, locus of control, and the theory of planned behavior 1. Journal of applied social psychology, 32(4), 665-683.

Assor, A., Kaplan, H., \& Roth, G. (2002). The choice is good, but relevance is excellent: Autonomyenhancing and suppressing teacher behaviours predicting students' engagement in schoolwork. British journal of educational psychology, 72(2), 261-278.

Bandura, A. (1986). Social foundations of thought and action. Englewood Cliffs, NJ, 1986(23-28).

Bandura, A. (1999). Social cognitive theory: An agentic perspective. Asian journal of social psychology, 2(1), 21-41.

Basu, A., \& Virick, M. (2008). Assessing entrepreneurial intentions amongst students: A comparative study. In VentureWell. Proceedings of Open, the Annual Conference (p. 79). National Collegiate Inventors \& Innovators Alliance. 
Begley, T. M., \& Boyd, D. P. (1987). Psychological characteristics associated with performence in entrepreneurial firms and smaller businesses. Journal of business venturing, 2(1), 79-93.

Bernstein, A. T., \& Carayannis, E. G. (2012). Exploring the value proposition of the undergraduate entrepreneurship major and elective based on student self-efficacy and outcome expectations. Journal of the Knowledge Economy, 3(3), 265-279.

Bird, B. (1988). Implementing entrepreneurial ideas: The case for intention. Academy of management Review, 13(3), 442-453.

Boden Jr, R. J., \& Nucci, A. R. (2000). On the survival prospects of men's and women's new business ventures. Journal of business venturing, 15(4), 347-362.

Boyd, N. G., \& Vozikis, G. S. (1994). The influence of self-efficacy on the development of entrepreneurial intentions and actions. Entrepreneurship theory and practice, 18(4), 63-77.

Brenner, O. C., Pringle, C. D., \& Greenhaus, J. H. (1991). Perceived fulfillment of organizational employment versus. Journal of small business management, 29(3), 62.

Brice Jr, J., \& Spencer, B. (2007). Entrepreneurial profiling: A decision policy analysis of the influence of entrepreneurial self-efficacy on entrepreneurial intent. Academy of entrepreneurship Journal, 13(2), 47-67.

Brush, C. G. (1992). Research on women business owners: Past trends, a new perspective and future directions. Entrepreneurship theory and practice, 16(4), 5-30.

Carr, J. C., \& Sequeira, J. M. (2007). Prior family business exposure as intergenerational influence and entrepreneurial intent: A theory of planned behavior approach. Journal of business research, 60(10), 1090-1098.

Chell, E., \& Baines, S. (2000). Networking, entrepreneurship and microbusiness behaviour Entrepreneurship \& regional development, 12(3), 195-215.

Chen, S. C., Hsiao, H. C., Chang, J. C., Chou, C. M., Chen, C. P., \& Shen, C. H. (2015). Can the entrepreneurship course improve the entrepreneurial intentions of students?. International Entrepreneurship and Management Journal, 11(3), 557-569.

Collins, O. F., \& Moore, D. G. (1970). The organization makers: A behavioral study of independent entrepreneurs. Appleton-Century-Crofts.

Dada, O., \& Watson, A. (2013). The effect of entrepreneurial orientation on the franchise relationship. International Small Business Journal, 31(8), 955-977.

Davidsson, P. (1995). Culture, structure and regional levels of entrepreneurship. Entrepreneurship \& Regional Development, 7(1), 41-62.

Delmar, F., \& Davidsson, P. (2000). Where do they come from? Prevalence and characteristics of nascent entrepreneurs. Entrepreneurship \& regional development, 12(1), 1-23.

Díaz-García, M. C., \& Jiménez-Moreno, J. (2010). Entrepreneurial intention: the role of gender. International entrepreneurship and management journal, 6(3), 261-283.

Dixon, R., Meier, R. L., Brown, D. C., \& Custer, R. L. (2005). The critical entrepreneurial competencies required by instructors from institution-based enterprises: A Jamaican study. Journal of STEM Teacher Education, 42(4), 4.

Drennan, J., Kennedy, J., \& Renfrow, P. (2005). Impact of childhood experiences on the development of entrepreneurial intentions. The International Journal of Entrepreneurship and Innovation, 6(4), 231-238.

Dyer Jr, W. G. (1995). Toward a theory of entrepreneurial careers. Entrepreneurship theory and practice, 19(2), 7-21.

Fiet, J. O. (2001). The theoretical side of teaching entrepreneurship. Journal of business venturing, $16(1), 1-24$.

Gibb, A. (2002). In pursuit of a new 'enterprise' and 'entrepreneurship'paradigm for learning: creative destruction, new values, new ways of doing things and new combinations of knowledge. International journal of management reviews, 4(3), 233-269.

Gird, A., \& Bagraim, J. J. (2008). The theory of planned behaviour as predictor of entrepreneurial intent amongst final-year university students. South African Journal of Psychology, 38(4), 711-724.

Hisrich, R. D. (1990). Entrepreneurship/intrapreneurship. American psychologist, 45(2), 209.

Hornaday, J. A., \& Aboud, J. (1971). Characteristics of successful entrepreneurs. Personnel psychology. 
Ismail, M., Khalid, S. A., Othman, M., Jusoff, H. K., Rahman, N. A., Kassim, K. M., \& Zain, R. S. (2009). Entrepreneurial intention among Malaysian undergraduates. International Journal of Business and Management, 4(10), 54-60.

Jo, H., \& Lee, J. (1996). The relationship between an entrepreneur's background and performance in a new venture. Technovation, 16(4), 161-211.

Kasouf, C. J., Morrish, S. C., \& Miles, M. P. (2015). The moderating role of explanatory style between experience and entrepreneurial self-efficacy. International Entrepreneurship and Management Journal, 11(1), 1-17.

Katz, J. A. (1992). A psychosocial cognitive model of employment status choice. Entrepreneurship theory and practice, 17(1), 29-37.

Kolvereid, L. (1996). Prediction of employment status choice intentions. Entrepreneurship Theory and practice, 21(1), 47-58.

Krueger Jr, N. F., Reilly, M. D., \& Carsrud, A. L. (2000). Competing models of entrepreneurial intentions. Journal of business venturing, 15(5-6), 411-432.

Krueger, N. F., \& Carsrud, A. L. (1993). Entrepreneurial intentions: Applying the theory of planned behaviour. Entrepreneurship \& Regional Development, 5(4), 315-330.

Krueger, N., \& Brazeal, P. R. (1994) How Believing in Ourselves Increases Risk Taking: Perceived Self-Efficacy and Opportunity Recognition. Decision Sciences, 25(3), 385-400.

Kuehn, K. W. (2008). Entrepreneurial intentions research: Implications for entrepreneurship education. Journal of Entrepreneurship Education, 11, 87.

Maes, J., Leroy, H., \& Sels, L. (2014). Gender differences in entrepreneurial intentions: A TPB multigroup analysis at factor and indicator level. European Management Journal, 32(5), 784-794.

Mair, J., \& Noboa, E. (2006). Social entrepreneurship: How intentions to create a social venture are formed. In Social entrepreneurship (pp. 121-135). Palgrave Macmillan, London.

Matlay, H., Dinis, A., do Paço, A., Ferreira, J., Raposo, M., \& Rodrigues, R. G. (2013). Psychological characteristics and entrepreneurial intentions among secondary students. Education+ Training.

Mazzarol, T., Volery, T., Doss, N., \& Thein, V. (1999). Factors influencing small business start-ups. International Journal of Entrepreneurial Behavior \& Research.

McClelland, D.C. (1961) The Achieving Society. Van Nostrand, Princeton, NJ.

Murphy, L., \& Lambrechts, F. (2015). Investigating the actual career decisions of the next generation: The impact of family business involvement. Journal of Family Business Strategy, 6(1), 33-44.

Perry, C. (1990) After Further Sightings of The Heffalump. Journal of Managerial Psychology 5, no.2: 22-31.

Pihie, Z. A. L., \& Bagheri, A. (2011). Teachers' and students' entrepreneurial self-efficacy: Implication for effective teaching practices. Procedia-Social and Behavioral Sciences, 29, 1071-1080.

Prottas, D. (2008) Do the self-employed value autonomy more than employees? Career Development International, 13(1), 33-45.

Rerup, C. (2005). Learning from past experience: Footnotes on mindfulness and habitual entrepreneurship. Scandinavian journal of management, 21(4), 451-472.

Reynolds, K. J., Turner, J. C., Haslam, S. A., \& Ryan, M. K. (2001). The role of personality and group factors in explaining prejudice. Journal of Experimental Social Psychology, 37(5), 427-434.

Robinson, P. B., Huefner, J. C., \& Hunt, H. K. (1991). Entrepreneurial research on student subjects does not generalize to real world entrepreneurs. Journal of Small Business Management, 29(2), 42.

Rotter, J. B. (1990). Internal versus external control of reinforcement: A case history of a variable. American psychologist, 45(4), 489.

Sata, M. (2013). Entrepreneurial intention among undergraduate business students. International Journal of Research in Management, Economics and Commerce, 3(9), 33-48.

Scherer, R. F., Adams, J. S., \& Wiebe, F. A. (1989). Developing entrepreneurial behaviours: A social learning theory perspective. Journal of Organizational Change Management.

Shane, S. (2000). Prior knowledge and the discovery of entrepreneurial opportunities. Organization science, 11(4), 448-469.

Shapero, A., \& Sokol, L. (1982). The social dimensions of entrepreneurship. Encyclopedia of entrepreneurship, 72-90. 
Singh, A.S. and Masuku, M.B. (2014) Sampling techniques \& determination of sample size in applied statistics research: An overview. International Journal of Economics, Commerce and Management, 2(11), pp.1-22.

Sitkin, S. B., \& Pablo, A. L. (1992). Reconceptualizing the determinants of risk behavior. Academy of management review, 17(1), 9-38.

Smilor, R. W. (1997). Entrepreneurship: Reflections on a subversive activity. Journal of Business venturing, 12(5), 341-346.

Souitaris, V., Zerbinati, S., \& Al-Laham, A. (2007). Do entrepreneurship programmes raise entrepreneurial intention of science and engineering students? The effect of learning, inspiration and resources. Journal of Business venturing, 22(4), 566-591.

Tavakol, M., \& Dennick, R. (2011). Making sense of Cronbach's alpha. International journal of medical education, 2, 53.

Uddin, M. R., \& Bose, T. K. (2012). Determinants of entrepreneurial intention of business students in Bangladesh. International Journal of Business and Management, 7(24), 128.

Van Gelderen, M.W., \& Jansen, P.G.W. (2006) Autonomy as a start-up motive. Journal of Small Business and Enterprise Development, 13(1), 23-32.

Weinstein, N. D. (1984). Why it won't happen to me: perceptions of risk factors and susceptibility. Health psychology, 3(5), 431.

Westhead, P., \& Solesvik, M. Z. (2016). Entrepreneurship education and entrepreneurial intention: Do female students benefit?. International Small Business Journal, 34(8), 979-1003.

Wilson, F., Kickul, J., \& Marlino, D. (2007). Gender, entrepreneurial self-efficacy, and entrepreneurial career intentions: Implications for entrepreneurship education. Entrepreneurship theory and practice, 31(3), 387-406.

Zellweger, T., Sieger, P., \& Halter, F. (2011). Should I stay or should I go? Career choice intentions of students with family business background. Journal of business venturing, 26(5), 521-536.

Zhao, H., Seibert, S. E., \& Hills, G. E. (2005). The mediating role of self-efficacy in the development of entrepreneurial intentions. Journal of applied psychology, 90(6), 1265. 